$\underset{T H E H A J}{\text { THEHA }}$ 



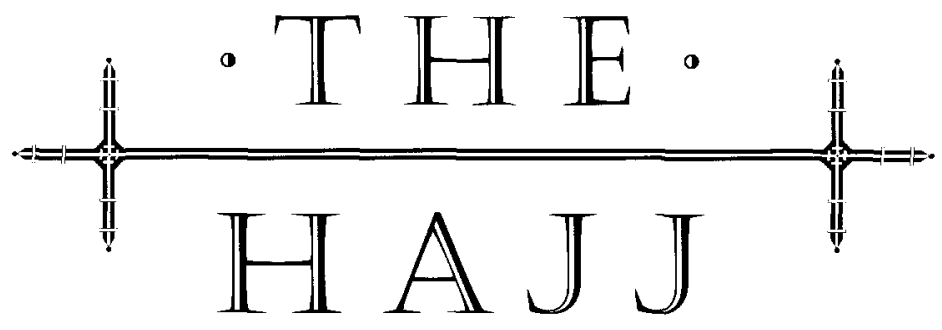

THE MUSLIM PILGRIMAGE TO

MECCA AND THE HOLY PLACES

\section{F. E. Peters}

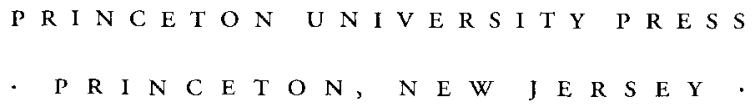


Copyright $(1994$ by Princeron University Press Published by Princeton University Press, 41 William Street,

Princeton, New Jersey 08540

In the United Kingdom: Princeton University Press,

Chichester, West Sussex

All Rights Reserved

Library of Congress Cataloging-in-Publication Data

Peters, F. E. (Francis E.)

The haji : the Muslim pilgrimage to Mecca and the holy places / F. E. Peters.

p. $\mathrm{cm}$.

Includes bibliographical references (p. ) and index ISBN 0-691-02120-1 ISBN 0-691-02619-X (PBK.)

1. Muslim pilgrims and pilgrimages-Saudi ArabiaMecca-History I. Tirle. BP187.3.P475 1994 $297^{\prime} .55--\mathrm{dc} 20 \quad 93-47292 \quad \mathrm{ClP}$

This book has been composed in Adobe Garamond

Princeton University Press books are printed on acid-free paper and meet the guidelines for permanence and durability of the Committee on Production Guidelines for

Book Longeviry of the Council on Library Resources

Printed in the United States of America by Princeton Academic Press

Second printing, and first paperback printing, 1996 


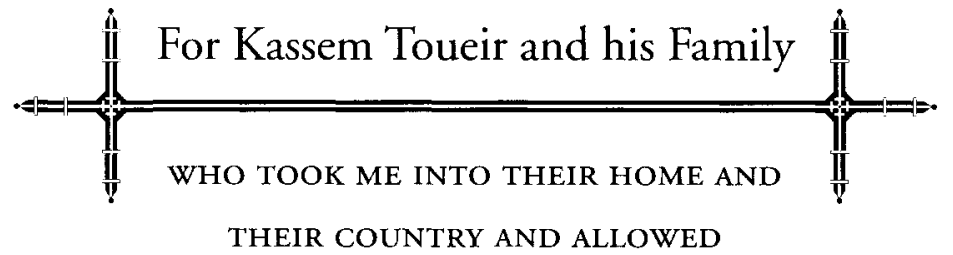

ME TO LOVE BOTH 
